\title{
DEVELOPMENT OF LIGNITE IN CRETE. COMPARISON OF BASINS, POSSIBILITIES OF EXPLOITATION
}

\author{
Karageorgiou D. E. ${ }^{1}$, Metaxas A. ${ }^{1}$, Karageorgiou M. M. D. ${ }^{2}$, \\ Papanikolaou G. ${ }^{3}$, Georgakopoulos A. N. ${ }^{4}$, Vrettos K. ${ }^{1}$ \\ ${ }^{1}$ Institute of Geology and Mineral Exploration, Olympic Village, Entrance C 13677, \\ Acharnae, Greece, dek@igme.gr \\ ${ }^{2}$ Geographer, 62 Amissou str.17123 N.Smyrni, Athens, Greece, melaxroini_ka@yahoo.gr \\ ${ }^{3}$ Geologist, Department of Geology, National \& Kapodistrian University of Athens, Greece, \\ geopapgr@gmail.com \\ ${ }^{4}$ Aristotle University of Thessaloniki, Department of Mineralogy-Petrology-Economic Geology, \\ Laboratory of Economic Geology, 54124 Thessaloniki,Greece,ageorgak@geo.auth.gr
}

\begin{abstract}
The island of Crete has been thoroughly explored, by various organizations, for the presence of lignite deposits, in order to examine the possibility of energy independence for the island and thus reduce the cost of consumed electric energy. Research showed that lignite generates in fluvial lacustrine environments in many places in Crete and lignite deposits have been investigated and exploited from time to time. In the present study all lignite occurrences of the island are recorded and their generation and depositional environment is analysed. Lignite horizons from different basins are compared and correlated. An evaluation of results from previous studies is attempted, regarding both surface information and depth data, derived from borehole projects. Finally, areas suitable for lignite exploitation in the production of electricity or other uses are presented.
\end{abstract}

Key words: lignite origin, lignite deposits, electricity, exploitation, Crete, South Greece.

\section{Introduction}

Exploratory works carried out in the island of Crete have shown the presence of lignite deposits in several areas. In some of them small-scale exploitation took place in the past.

The electric power consumed in the island of Crete reaches $3050 \mathrm{Gw} / \mathrm{h}$ per year and is either transported from the mainland or produced in Steam Electric Stations using oil.

The aim of this study is to present the lignite deposits recorded by investigations carried out by Institute of Geology and Mineral Exploration of Greece (IGME) in the island of Crete (fig.1) regarding both surface information and depth data. An analysis of the origin and depositional environments is attempted, given that they are mainly located in fluvial-lacustrine environments with successive sea transgressions. Moreover, the lignite horizons from different basins are correlated. This study can contribute to the reduction of the electric power costs and achieve energy independence for the island of Crete. 


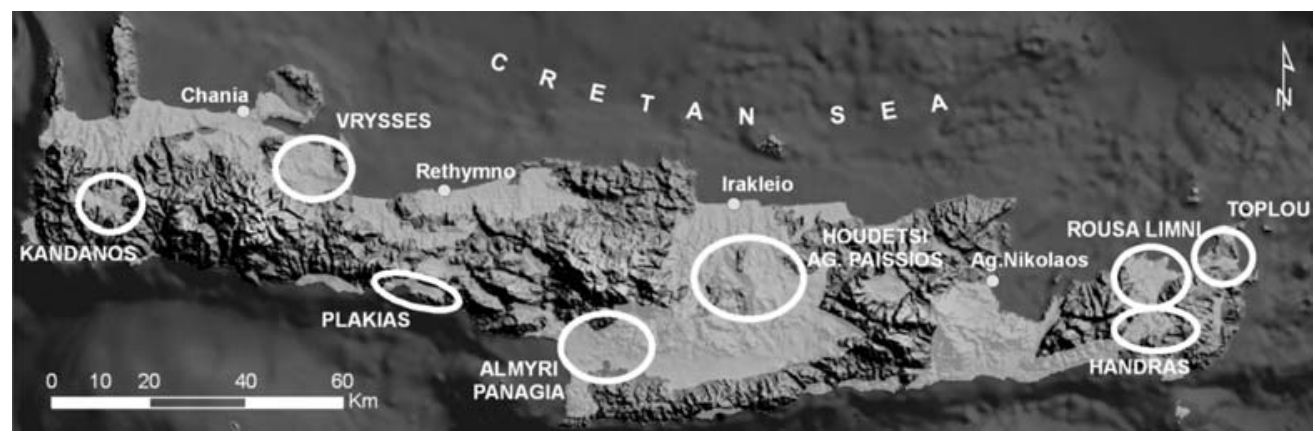

Fig. 1: Neogene's and Quaternary lignite areas of Crete Island.

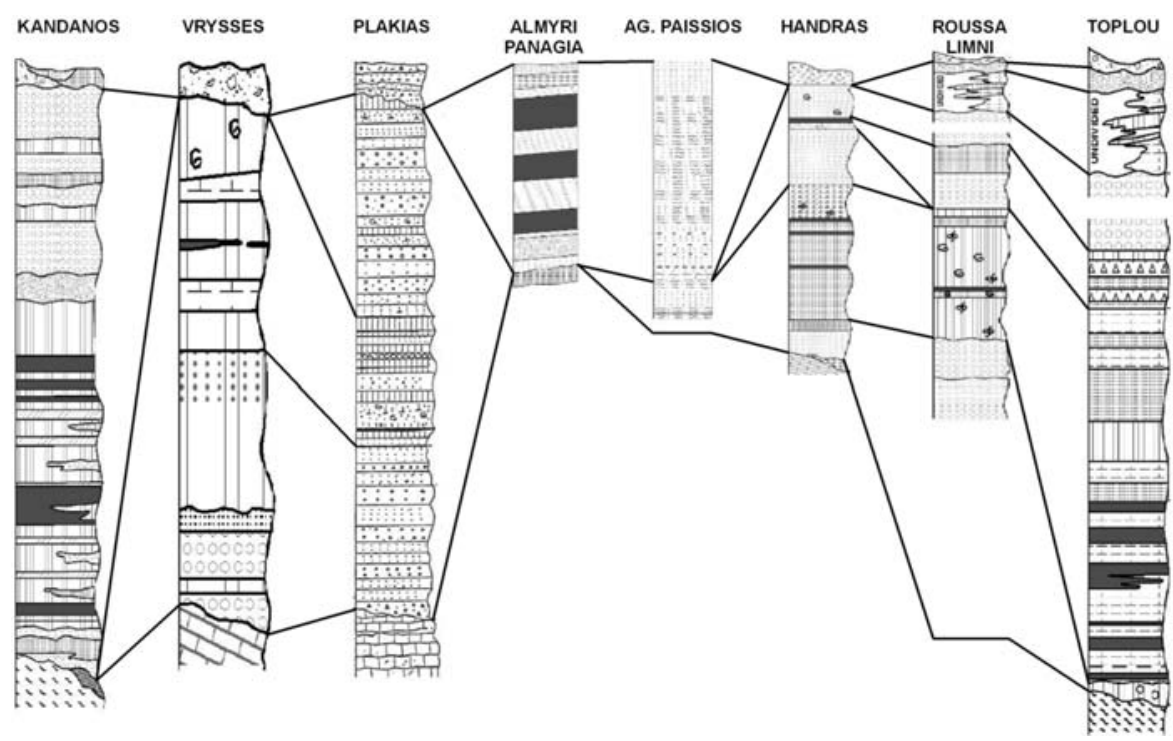

Fig. 2: Stratigraphic correlation of the lignite areas of Crete Island.

\section{Geological setting}

In the island of Crete the lignite deposits are located into the Miocene fluvial-lacustrine formations, with exception of Kandanos to the West and Almyri Panagia in the Central and South part of the island basins. (Karageorgiou, 1952).

Lignite was deposited into fluvial-lacustrine formations consisting of clays, sands and marls. Fossils - neritina, potamites, melanopsis, etc. - are observed into these formations (Vetoulis, 1952). Frequent sea transgressions are also observed separating the lignite beds.

The general stratigraphic column of the lignite basins is described below:

- Bedrock: consists of the rocks of the formations of Tripolis zone (Jurassic to Middle Eocene Limestones, Flysch of Upper Eocene to Oligocene), Pindos zone (Upper Cretaceous Limestones, Flysch of Paleocene to Eocene), as well as of the ophiolithic complex of the internal zones.

- Formation of the Base: consists of a polymict conglomerate, breccias, sands, red clays, with thickness ranging from a few centimetres to some tens of meters. It overlies the bedrock and 

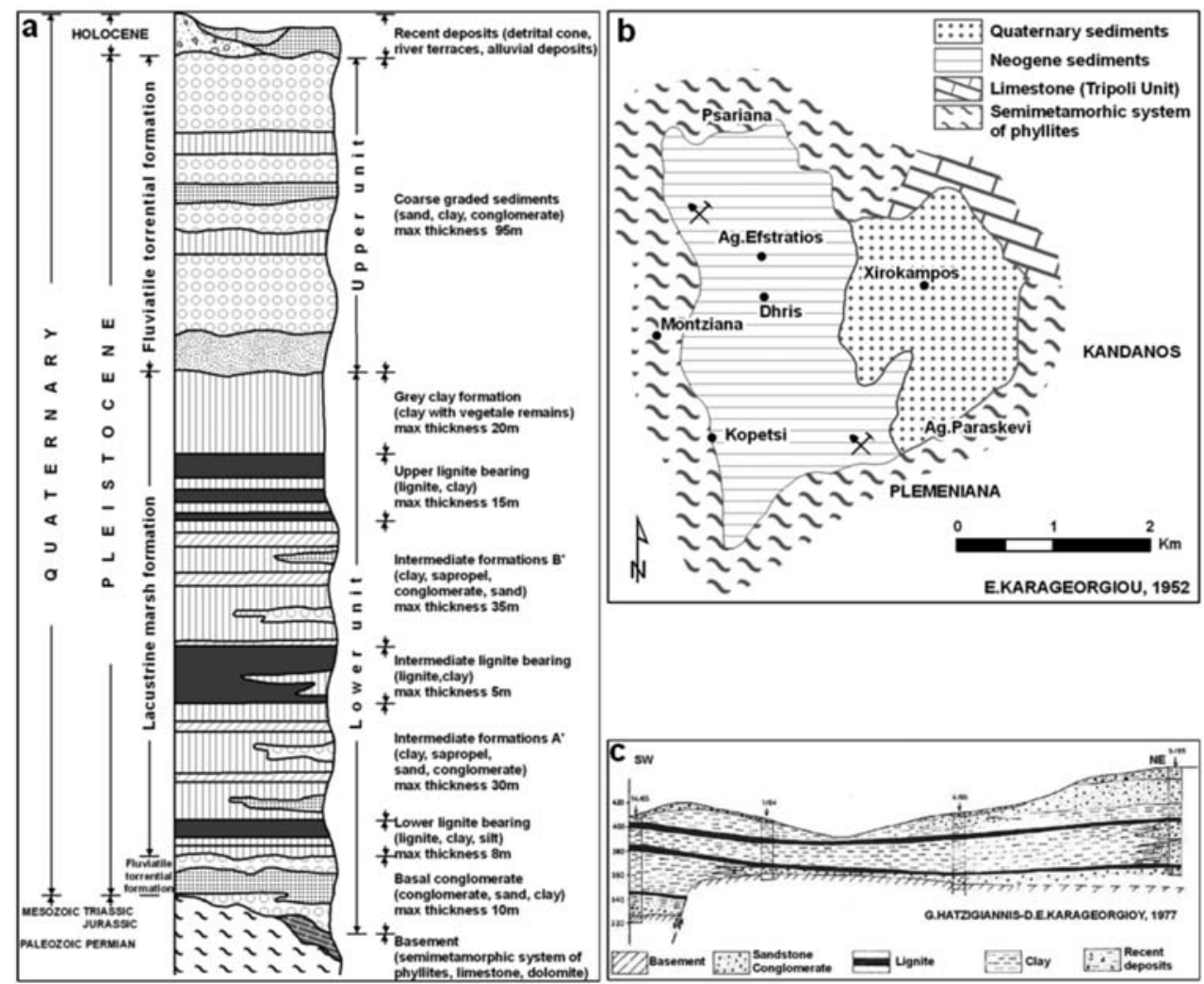

Fig. 3: (a): Stratigrafic column of Kandanos area; (b): Geological map of Kandanos area; (c): Geological section of boreholes in Kandanos area.

smoothes its erosions. In the areas of Almyri Panagia and Handra these sediments are of marine origin and different age: Upper Pliocene and Miocene respectively.

- Lacustrine-marshy and fluvial-lacustrine phase: consists of marls, clays, sands and silts and hosting lignite beds of various thicknesses. This phase is of Miocene age apart from the areas Almyri Panagia and Kandanos, which are of Pleio-Pleistocene age.

- Fluvial-torrential or marine formations: closing the Neocene series. The marine formations consist of a transgression conglomerate and sands, clays with Ostrea, Pecten, etc. fossils and the fluvial-torrential formations of sands, clays, conglomerates and breccias.

- Recent formations: alluvial deposits, talus cones, clays, sands, unconsolidated conglomerates (Fig. 2).

\section{Areas of Interest}

\subsection{Kandanos}

The area is located to the South-West of Chania city at a distance of $60 \mathrm{~km}$., occupying an extent of about $10 \mathrm{~km}^{2}$. Only the West - North West part of $1 \mathrm{~km}^{2}$ area has been investigated in the past, (Karageorgiou, 1951) since it is of great geological interest and Germans have exploited the lignite of this section during the period 1940-1944. 


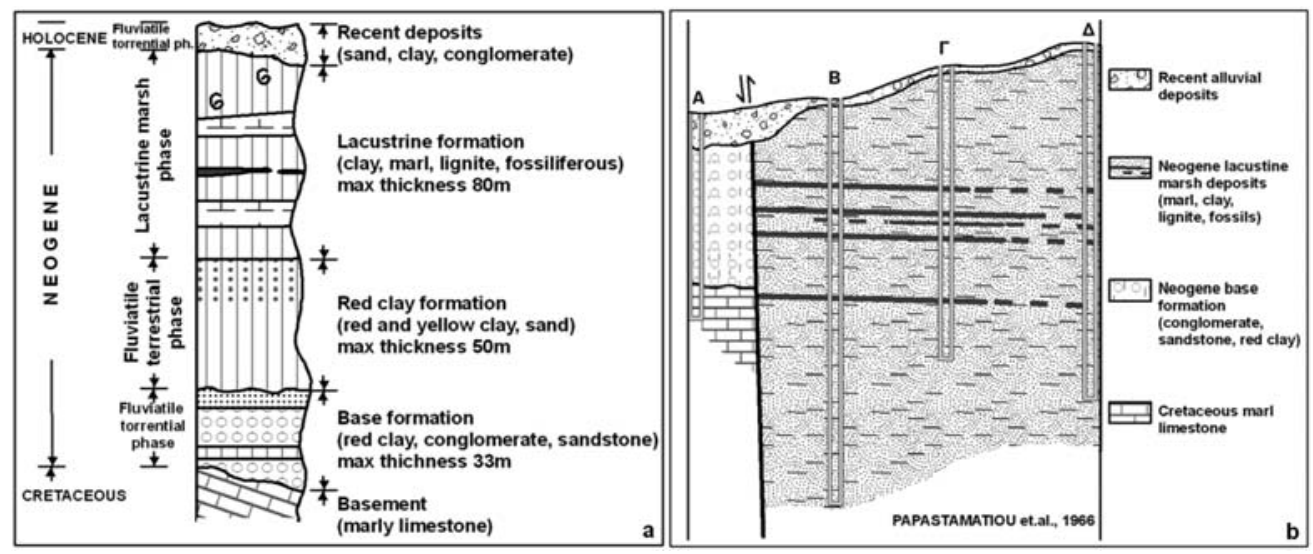

Fig. 4:(a): Stratigraphic column of Vrysses area; (b): Geological section of boreholes in Vrysses area.

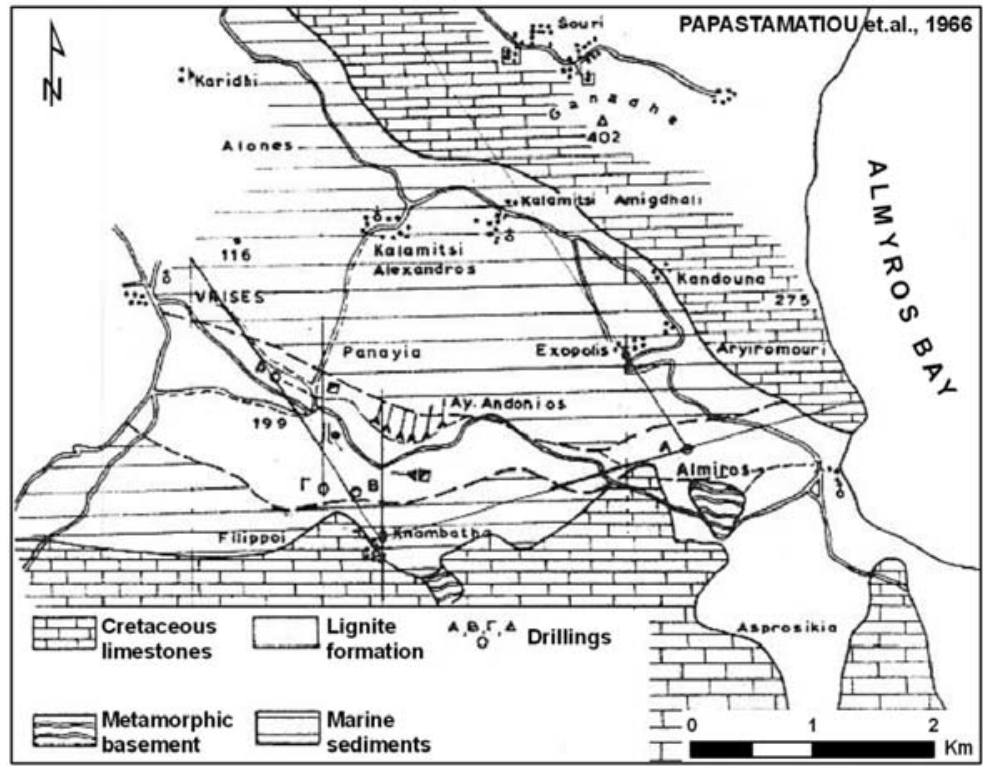

Fig. 5: Geological map of Vrysses area.

The geological formations (Chatzigiannis and Karageorgiou 1977) observed in the area are shown in the stratigraphic column (Fig. 3a) and the geological map (Fig. 3b).

Three main lignite beds are located in Kandanos area (Fig. 3c) having 9 million tons as potential reserves. These lignite beds can be exploited by open-pit mining with an exploitation ratio ranging from 2.3 to $11 / 1$. The Gross Calorific Value [on an a.r. (as received) basis] is of $1700 \mathrm{Kcal} / \mathrm{Kg}$.

The region should be systematically investigated as a whole in order to increase the exploitable lignite reserves.

\subsection{Vryses}

This area is located east of Chania city at a distance of $20 \mathrm{~km}$. The geological formations observed in the area are shown in the stratigraphic column (Fig. 4a) and the geological map (Fig. 5). 


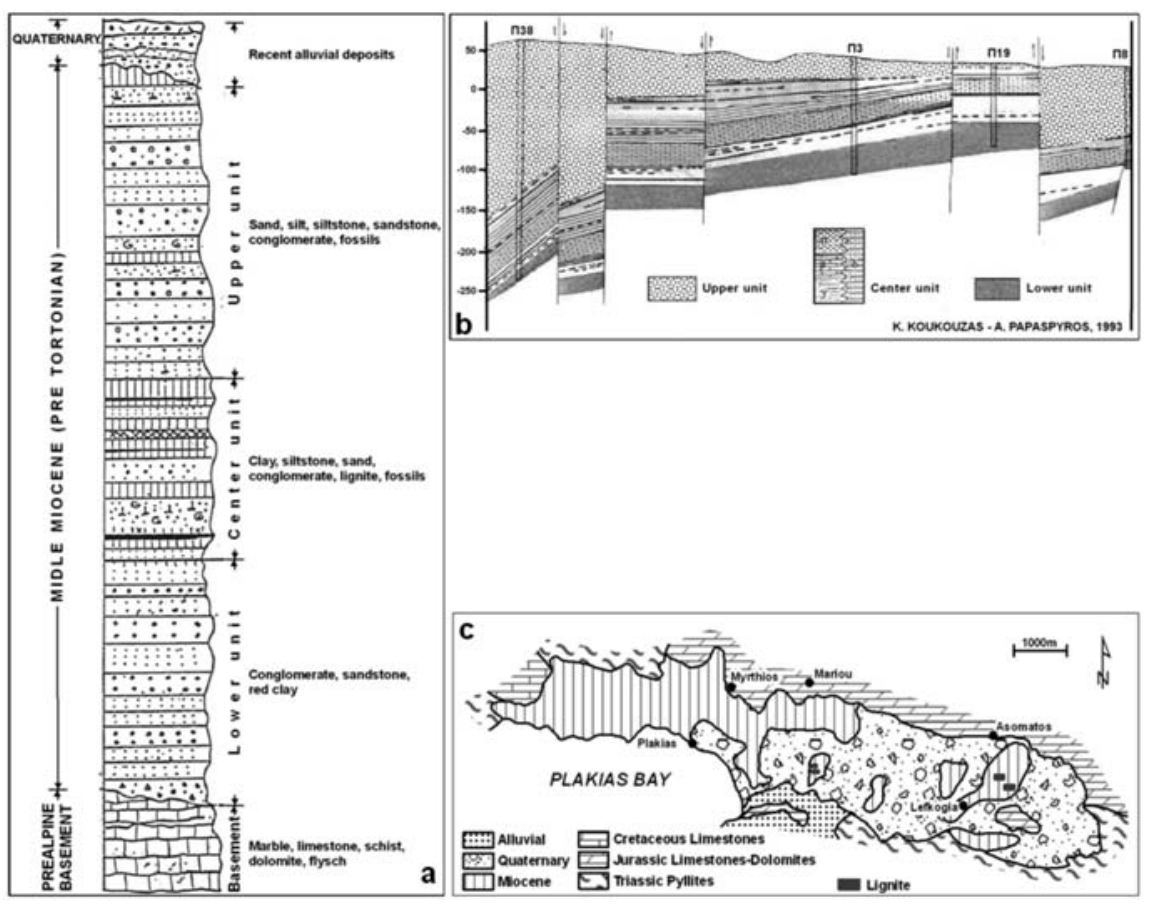

Fig. 6: (a): Stratigraphic column of Plakias area; (b): Geological section of boreholes in Plakias area; (c): Geological map of Plakias area.

Four lignite beds (Fig. 4b) were located in the area of Vryses Apokoronou. Previous investigations (Papachristos, 1952) demonstrated that there is apparent economic interest in the region.

\subsection{Plakias - Lefkogia}

The area is located south of Rethymno city at a distance of $35 \mathrm{~km}$, occupying an area of $10 \mathrm{~km}^{2}$ and has been repeatedly exploited in the past. From the extended mineralogical and geological investigation of the area carried out by I.G.M.E. (Koukouzas and Papaspyros 1993) $2.3 \mathrm{~m}$. tons of strongly tectonized mineable lignite were located with an average Net Calorific Value [on an a.r. (as received) basis] $>2.000 \mathrm{Kcal} / \mathrm{Kg}$ as illustrated in Fig. 6b.The geology of the area is shown in the stratigraphic column (Fig. 6a) and the geological map (Fig. 6c).

\subsection{Almyri Panagia}

The area is located to the south of Iraklio city at a distance of $40 \mathrm{~km}$ occupying an area of $8 \mathrm{Km}^{2}$.

Restricted investigation including drilling of a few boreholes of small depth was carried out in the past (Papastamatiou et al., 1966). Four lignite beds were located (Fig. 7) having geological reserve in the order of 4.5 million tons and thickness of lignite beds varying from $2.70 \mathrm{~m}$ to $5.20 \mathrm{~m}$ (Papaspyros 1993). The geology of the area is shown in the stratigraphic column (Fig. 8a) and the geological map (Fig. 8b). 


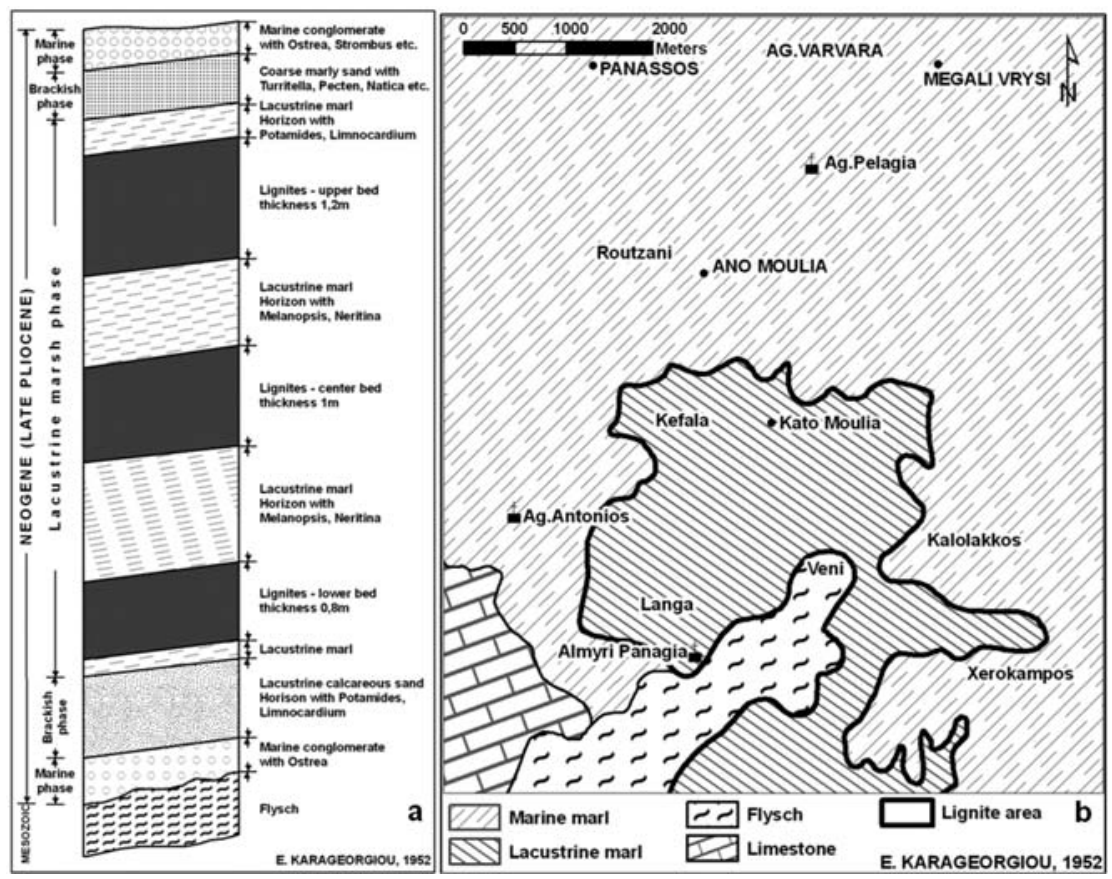

Fig. 7: (a): Stratigraphic section of lignite outcrop in Almyri Panagia area; (b): Geological map of Almyri Panagia area.

\subsection{Agios Paisios - Houdetsio}

The area is located to the South-East of Iraklio city and at a distance of $20 \mathrm{~km}$, occupying an area of $18 \mathrm{~km}^{2}$.

The area is covered by lacustrine sediments of Miocene age with overlying marine Miocene formations (Koukouzas and Papaspyros 1984). The lacustrine sediments occupy much greater extent than the aforementioned (the $18 \mathrm{~km}^{2}$ ).

\subsection{Handras}

The area is located to the South of Sitia city at a distance of $20 \mathrm{~km}$, occupying an area of 4,5 $\mathrm{km}^{2}$.

During Miocene three sea transgressions took place in the area alternating with two fluvial-marshy phases including the lignite beds of 30cm average depth (Maratos, 1952). Apart from the surface observation (Figs 8a, 8b) no other exploratory work was implemented in the area.

\subsection{Roussa Limni}

It is located at the margins of Sitia city occupying an extent of about $35 \mathrm{~km}^{2}$. Besides the geological mapping (Fig. 9b) and surface recordings, no further investigation was carried out in the area. The surface observation leads to the conclusion that the marine deposition of the sediments was interrupted by a small period of deposition of lacustrine-lacustrine-marshy sediments of $6 \mathrm{~m}$ thickness, resulting in lignite generation without any economic interest (Fig. 9a). At the margins of the basin, 


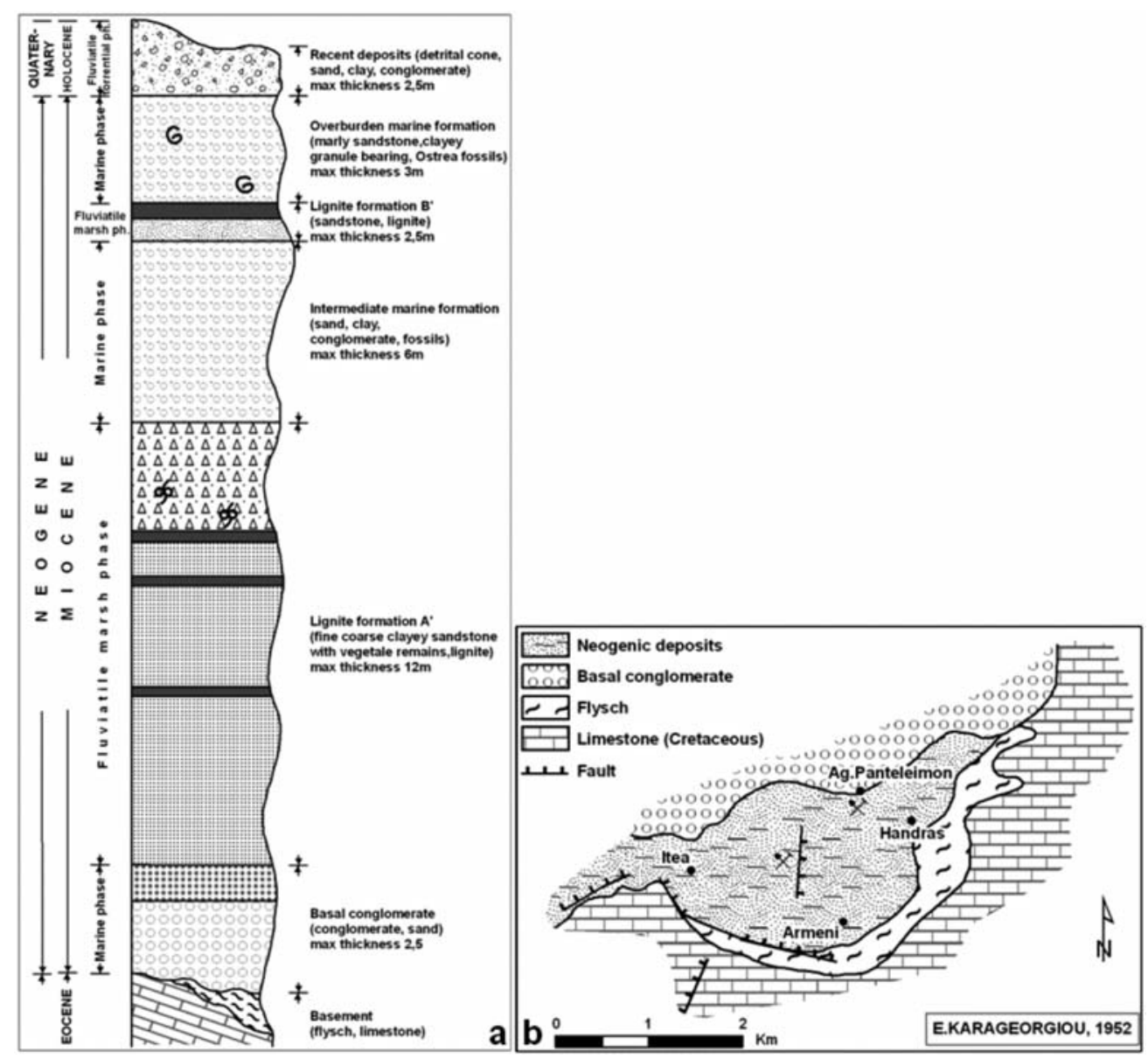

Fig. 8: (a): Stratigraphic column of Handras area; (b): Geological map of Handras area.

to the west of Sitia city, a small occurrence of lacustrine Pliocene formations is observed with potential lignite deposition (Karageorgiou, 1978).

\subsection{Toplou monastery}

It is located East of Sitia city at a distance of $18 \mathrm{~km}$, occupying an area of $20 \mathrm{~km}^{2}$. The development of the geological formations in the area is similar to this of Lake Roussa area (Fig. 10b).The drilled borehole for irrigation of the cultivations provides the only evidence for the existence of lignite beds in the area where a lignite seam of $40 \mathrm{~m}$ thickness was found at a depth of about 70m (Fig. 10a). In order to confirm the occurrence of "blind" lignite deposit, this area should be further investigated (Karageorgiou, 1978).

\section{Possibility of lignite deposits use}

According to the data from the Public Power Corporation (P.P.C.), the electricity needs in Crete amount annually to $3050 \mathrm{Gw} / \mathrm{h}$. To produce this energy, two units of $300 \mathrm{MWatt}$ each are required. 


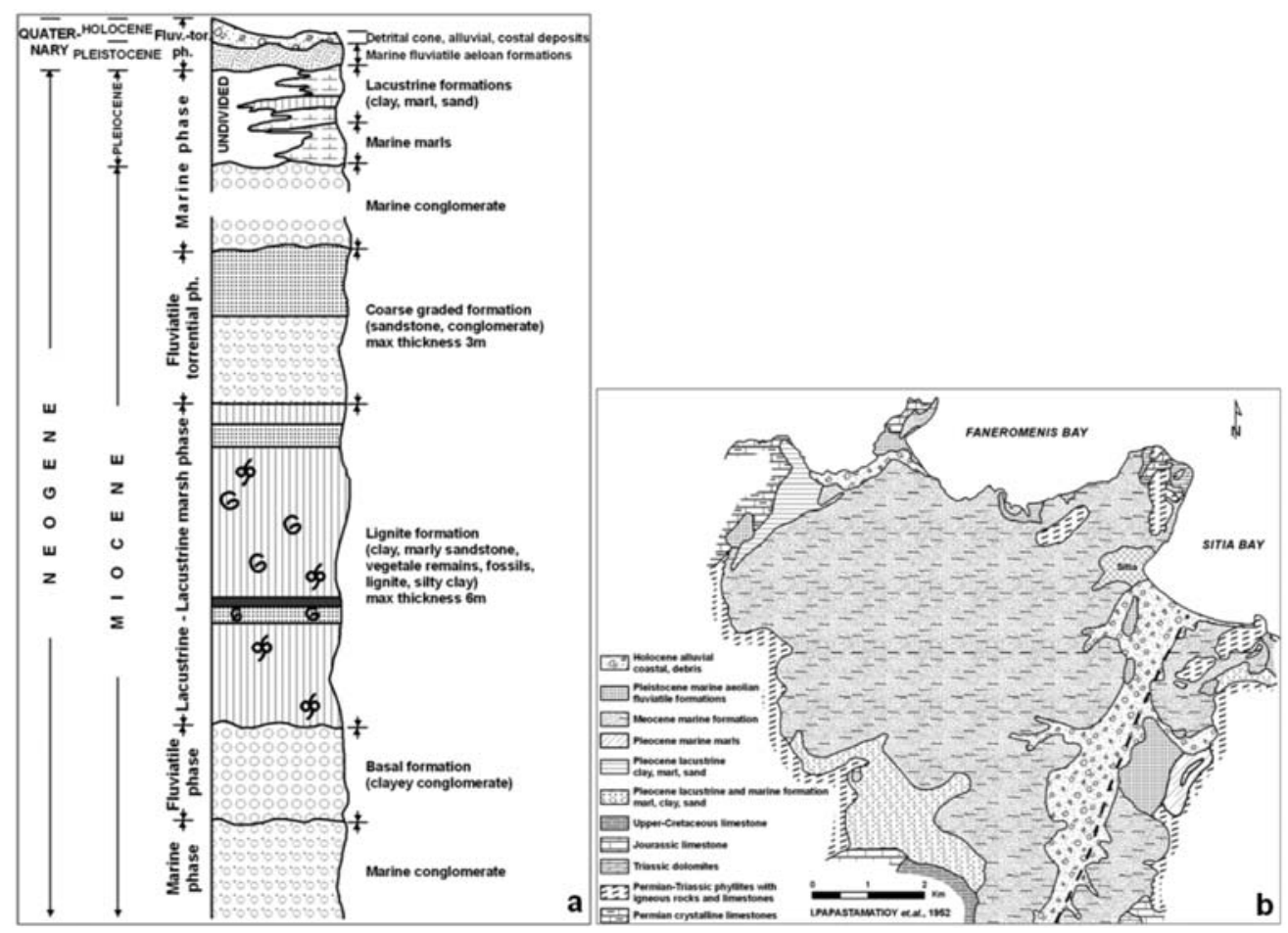

Fig. 9: (a): Stratigraphic column of Roussa Limni area; (b): Geological map of Roussa Limni area.

Burning oil produces the higher percentage. According to data obtained from the investigations so far on the island, a unit of 150Mwatt can be constructed and run with the existing lignite reserves. These reserves will increase if the potential lignite reserves of the island of Crete will be explored more systematically. At least $25 \%$ of the electricity consumed can be covered by the use of lignite instead of oil as fuel with lower costs and hence lower prices paid by the consumer. On the other hand carbon dioxide and other heat-trapping gases are declared as pollutants and endanger public health and welfare. Man-made $\mathrm{CO}_{2}$ released into the atmosphere is a significant contributor to the greenhouse gas effect and related global warming. This fact must be taken into account in an island with important tourist industry. With plans to drastically reduce the venting of $\mathrm{CO}_{2}$ through capture at the source [Carbon Capture and Storage (C.C.S.) Technology], vast volumes of $\mathrm{CO}_{2}$ will need to be sequestered and it is expected that $\mathrm{CO}_{2}$ capture and storage in the subsurface and monitoring are going to be of major importance in the future. Pilot Projects concerning carbon sequestration are under development worldwide. In the case of Crete, storage-related research should be done, in the sea at great depths or below evaporitic horizons, in order to estimate the $\mathrm{CO}_{2}$ storage capacities. In parallel, other methods than the conventional ones for the lignite exploitation and combustion can be applied to reduce the environmental impact. As an example the in situ combustion is mentioned.

In the recent years an investigation was carried out by the Institute of Geology and Mineral Exploration (I.G.M.E.) under the Community Support Framework programs, on the possible uses of lignite in other applications than electricity production (I.G.M.E. Final Report: Study and Research of selected Solid Fuel deposits for application in other than electricity uses, ISBN 978-960-87453-22, 2008). 


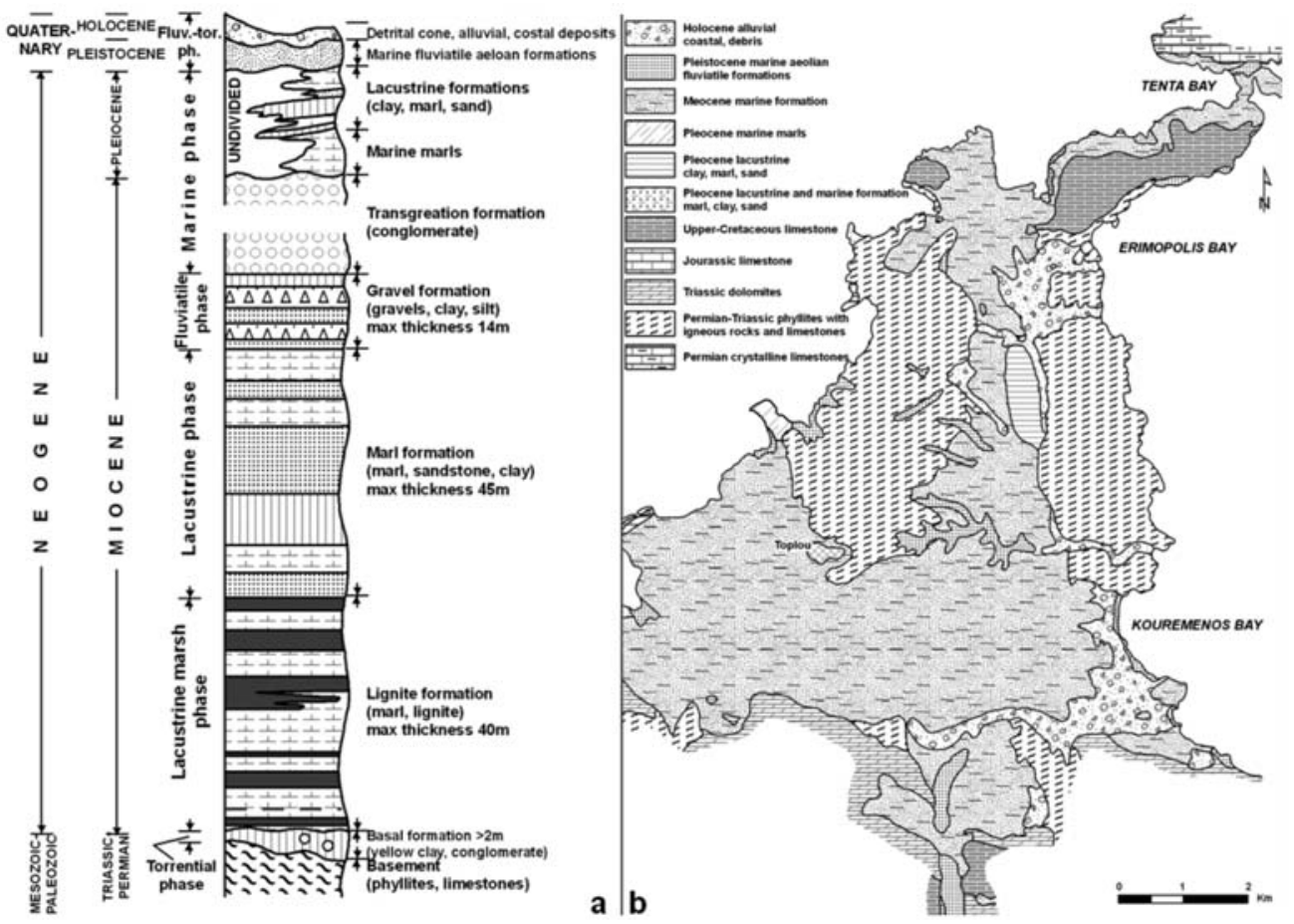

Fig. 10: (a): Stratigraphic column of Toplou area; (b): Geological map of Toplou area.

It was concluded that Crete lignites may be suitable for use as additives in drilling mud, as a soil improvement product and as a pollutant-removing material contributing to the increase of their economic value.

\section{Conclusions-Results}

Lignite basins mainly of Miocene age develop in the island of Crete. The total reserves of these basins amount 25,000 million tons. Among these reserves some millions tons can be exploited. Since the electric power requirements in the island of Crete reaches $3.050 \mathrm{Gw} / \mathrm{h}$ annually, mostly covered by the use of oil, lignites exploitation can contribute to a dependency reduction of at least $25 \%$. This lignite exploitation can be achieved using new technologies in order to reduce the impact on the environment and offer cheaper and cleaner energy. In this purpose a more systematic investigation of the lignite deposits in the island of Crete is necessary. The use of lignites in other than electricity production applications is also possible.

\section{References}

Chatzigiannis, G. and Karageorgiou D.E., 1977. Mineralogical reconnaissance in Kandanos lignite basin, Chania region, Crete. I.G.M.E. Athens p.14 (in Greek).

I.G.M.E. Final Report: Study and Research of selected Solid Fuel deposits for application in other than electricity uses, ISBN 978-960-87453-2-2, 2008.

Karageorgiou, D.E., 1978. Geological and Mineralogical reconnaissance of the Neocene basins of the 
Lassithi region, Inland Crete. I.G.M.E. Athens p.6 (in Greek).

Karageorgiou, E.D., 1951. Geological reconnaissance of the lignite area of Kandanos - Psariana, in Crete inland. I.G.S.R. Athens p.6 (in Greek).

Karageorgiou, E.D., 1952. Geological reconnaissance of the lignite areas of Crete inland. I.G.S.R. Athens p.20 (in Greek).

Koukouzas, K. and Papaspyros, A., 1984. Mineralogical reconnaissance of lignite in the areas Toplou, Handra of Lassithi region and Houthetsio of Iracklion region. I.G.M.E. Athens p.7 (in Greek).

Koukouzas, K. and Papaspyros, A., 1993. Lignite exploration of Plakia basin of Rethymnon, Crete. I.G.M.E. Athens p.82 (in Greek).

Maratos, G., 1952. The appearances of lignite in Lassithi region. I.G.S.R. Athens p.6 (in Greek).

Papachristos, G., 1952. Lignite exploration of Vrises Apokoronou and Fournes basins of Chania Crete. I.G.S.R. Athens p.10 (in Greek).

Papaspyros, A., 1993. Lignite exploration of Almyri Panagia area of Iraklion region. Crete. I.G.M.E. Athens p.78 (in Greek).

Papastamatiou, J., Vetoulis D., Brousoulis, J., 1966. Lignite exploration of Almyri Panagia basin, of Vryses Apokoronou basin and of Kandanos basin, Crete. I.G.S.R. Athens p.30 (in Greek).

Vetoulis, D., 1952. Lignite exploration of Iraclion basins, Crete. I.G.S.R. Athens p.15 (in Greek). 